\title{
Faktor Risiko Early Childhood Caries pada Anak UsiaPrasekolah di PAUD Kenanga 17 Kelurahan Penjaringan, Kecamatan Penjaringan, Jakarta Utara
}

\section{Risk factor of early childhood caries in preschool children ofPAUD Kenanga 17 Kelurahan Penjaringan, KecamatanPenjaringan, NorthJakarta}

\author{
Anita Rosa Delima, Setya Kusuma Arum \\ Prodi Kedokteran Gigi, Fakultas Kedokteran \\ Universitas YARSI, Indonesia
}

KEYWORDS

Dental caries, risk factors of early childhood caries, preschool children, formula milk

ABSTRACT Dental caries is a multifactorial disease that can affect all levels of society. There are several factors that take part ini caries initiation. Caries risk factors in children are related to age, gender, use of bottles, tooth brushing frequency, the role of the mother, and parental education. The purpose of this studywas to find out factors related to the cause of early childhood caries experienced by preschool children at PAUD Kenanga 17 Kelurahan Penjaringan, Kecamatan Penjaringan, North Jakarta. An observational analytical methods with cross sectional approach was used in this study. Subject in this study consisted of 20 children as a total sample of the population. Data collection was carried out using questionnaires and def-t index was employed for dental examination. Data processing and statistical analysis using chi-square test were applied with a significance value of $p$ $<0.05$. The results showed significant correlation between age ( $p$ value 0.001) and gander ( $p$ value 0.047) andearly childhood caries.hawever, no correlation was observed betwen the use of bottle ( $p$ value $=0.909$ ), frequency of tooth brushing ( $p$ value 1.00), role of mother ( $p$ value 1.00), and parental education ( $p$ value $=0.798$ ) and early childhood caries. 


\section{ANITA ROSA DELIMA}

\section{PENDAHULUAN}

Karies gigi merupakan masalah kesehatan yang umum terjadi di negara maju maupun negara berkembang, termasuk Indonesia. Hasil survei Riset Kesehatan Dasar menunjukkan bahwa $53,2 \%$ penduduk Indonesia menderita karies gigi aktif atau kerusakan pada gigi yang belum ditangani (RISKESDAS, 2013).

Karies merupakan penyakit multifaktorial yang dapat menyerang semua lapisan masyarakat (Prasetya, 2008).

\section{Early Childhood Caries (ECC)} merupakan karies yang mengenai anak usia dini. Meskipun tidak mengancam jiwa, namun penyakit ini dapat menyebabkan penurunan nafsu makan, yang akhirnya mengakibatkan kekurangan gizi, gangguan fungsi, berat badan, dan kemampuan pada anak untuk berkembang yang akhirnya berdampak pada kualitas hidup(Zafar dkk, 2009).

ECC terjadi jika terdapat faktor-faktor seperti host, agen, substratdan waktu. Selain itu, ECC juga dipengaruhi oleh umur, jenis kelamin, pendidikan orang tua, peran ibu, dan faktor kebiasaan (Prasetya, 2008).

Anak usia prasekolahrentan terhadap penyakit gigi dan mulut karenaumumnya masih mempunyai perilaku atau kebiasaan diri yang kurang menunjang terhadap kesehatan gigi (Mintjelungan, 2014).Anak-anak cenderung menyukai makan-makanan manis yang lengket dan jarang membersihkan gigi (Sumini dkk, 2013). Karies pada anak kurang mendapat perhatian karena dianggap tidak membahayakan jiwa dan nantinya gigi sulung akan diganti dengan gigi permanen. Kenyataannya, apabila gigi sulung dibiarkan rusak dan berlubang dapat menyebabkan kerusakan pada gigi permanen nantinya (Wirjayadi dkk, 2013).

Berdasarkan latar belakang tersebut, penelitian ini dilakukan untuk melihat status ECC berdasarkan faktor risiko Early Childhood Caries pada anak usia prasekolah.

\section{METODE PENELITIAN}

Penelitian ini merupakan penelitianobservasional analitik dengan desain potong-lintang (cross sectional). Penelitian dilakukan di PAUD Kenanga 17 kelurahan Penjaringan, kecamatan Penjaringan, Jakarta Utara pada tanggal 11 November 2015.

Sampel penelitian ialah siswa/siswi PAUD Kenanga 17 kelurahan 
Penjaringan, kecamatan Penjaringan, dicabut (e), dan gigi yang ditambal (f).

Jakarta Utara.Besar sampel sebanyak 80 orang dan pengambilan sampel dilakukan dengan teknik total sampling.

Kriteria inklusi adalah anak yang mengonsumsi susu formula dan diizinkan oleh orangtua/wali untuk mengikuti penelitian ini. Sedangkan kriteria ekslusi adalah anak yang tidak mengonsumsi susu formula dan tidak diizinkan oleh orangtua/wali untuk mengikuti penelitian.

Sebelum dilakukan pengumpulan data, seluruh siswa/siswi PAUD Kenanga 17 kelurahan Penjaringan, kecamatan Penjaringan, Jakarta Utara yang sesuai kriteria inklusi diberikan informed consent yang selanjutnya akan diisi oleh orangtua/wali.

Pengambilan data pada sampel penelitian dilakukan dengan dua metode pengukuran. Data primer mengenai faktor risiko ECC dikumpulkan dengan menggunakan kuesioner, sedangkan status ECC dilihat dengan melakukan pemeriksaan keadaan rongga mulut. Tabel 1. memperlihatkan data variabel penelitian yang diperoleh melalui kuesioner. Pemeriksaan status ECC dilakukan oleh dokter gigi umum dibantu dengan mahasiswa kedokteran gigi. Pemeriksaan dilakukan pada semua gigi untuk melihat berapa gigi yang terkena karies (d), gigi yang berindikasi untuk
Hasil ini dicatat dalam lembar pemeriksaan.

Analisis dilakukan menggunakan analisis univariat dan bivariat.Analisis univariat menghasilkan distribusi dan presentase dari setiap variabel yang diteliti. Analisis bivariatdilakukan untuk melihat hubungan variabel bebas dan variabel terikat dengan menggunakan uji Chi-square dengan kemaknaan $(\alpha)$ 0,05.

\section{HASIL PENELITIAN}

Karakteristik responden disajikan dalam Tabel 2. Diperoleh data bahwa usia responden $<5$ tahun sebesar $37.5 \%$, yang berusia $\geq 5$ tahunsebesar $62.5 \%$. Sebanyak $55 \%$ dari responden adalah perempuan dan $45 \%$ adalah laki-laki.

Tabel 1. Variabel Penelitian dan kategori variable

\begin{tabular}{ll}
\hline \multicolumn{1}{c}{ Kategori } & \multicolumn{1}{c}{ Variabel } \\
\hline Usia & $<5$ tahun \\
Jenis kelamin & $\begin{array}{l}\text { Perempuan } \\
\text { laki-laki }\end{array}$ \\
Penggunaan botol & $\begin{array}{l}\text { Menggunakan } \\
\text { Tidak menggunakan }\end{array}$ \\
Kebiasaan & $\begin{array}{l}\text { 1 kali/ hari } \\
\text { menyikat gigi }\end{array}$ \\
Peran ibu & $\begin{array}{l}\text { Menggunakan ali hari makan } \\
\text { bergantian } \\
\text { Tidak } \\
\text { alatmakan bergantian }\end{array}$ \\
& $\begin{array}{l}\text { Tinggi } \geq \text { S1 } \\
\text { Rendah } \leq \text { SMA }\end{array}$ \\
\hline
\end{tabular}

Responden yang mengonsumsi susu formula menggunakan botol lebih banyak (57.5\%) dibandingkan yang tidak menggunakan botol (42.5\%). Jumlah 


\section{ANITA ROSA DELIMA}

responden yang menyikat gigi/hari sebanyak 63 orang $(78.8 \%)$ sedangkan yang hanya 1 kali/hari sebanyak 17 orang (21.3\%).Sebanyak $\quad 49 \% \quad$ responden menunjukan adanya peran ibu dalam penggunaan alat makan bersama, dan kebanyakan orang tua memiliki pendidikan yang tinggi $(62.5 \%)$. Hasil analisis bivariat diperoleh bahwa ada hubungan antara usia dan jenis kelamin dengan terjadinya ECC.

Tabel 2. Distribusi responden berdasarkan usia

\begin{tabular}{lll}
\hline Variabel & Frekuensi & Presentase \\
\hline Usia & & \\
$<5$ tahun & 30 & 37.5 \\
$\geq 5$ tahun & 50 & 62.5 \\
Jenis & & \\
kelamin & & 55 \\
$\begin{array}{l}\text { Perempuan } \\
\text { Laki-laki }\end{array}$ & 44 & 45 \\
$\begin{array}{l}\text { Penggunaan } \\
\text { botol }\end{array}$ & & \\
$\quad$ Ya & 46 & 57.5 \\
$\quad$ Tidak & 34 & 42.5 \\
Frekuensi & & \\
menyikat & & \\
gigi & & \\
1 kali/ hari & 17 & 21.3 \\
2 kali/ hari & 63 & 78.8 \\
Peran Ibu & & \\
Ya & 31 & 38.8 \\
Tidak & 49 & 61.3 \\
Pendidikan & & \\
orang tua & & \\
Rendah & 30 & \\
Tinggi & 50 & \\
\hline
\end{tabular}

Tabel 3. memperlihatkan distribusi responden berdasarkan terjadinya ECC, responden yang terjadi ECC lebih banyak (86.3\%) dibandingkan dengan yang tidak terjadi ECC (13.8)\%.

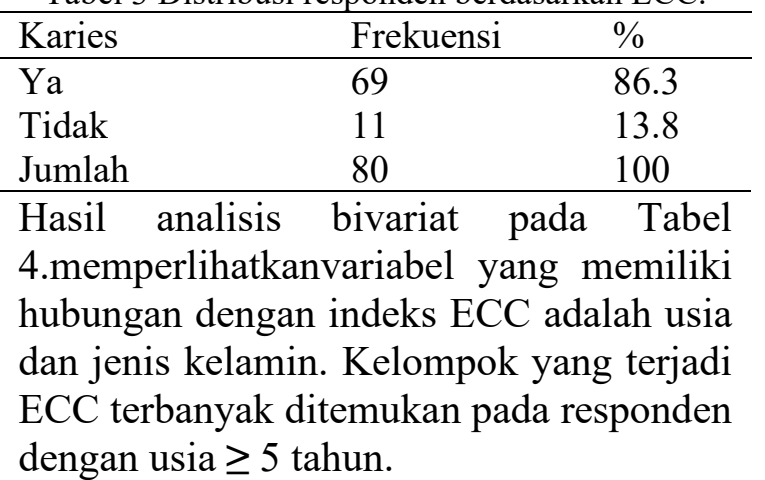

Tabel 4 Faktor-faktor yang berhubungan terhadapindeks ECC

\begin{tabular}{|c|c|c|c|c|c|}
\hline \multirow{3}{*}{ Variabel } & \multicolumn{4}{|c|}{ Indeks ECC } & \multirow{3}{*}{$\begin{array}{l}P \\
\text { value }\end{array}$} \\
\hline & \multicolumn{2}{|c|}{$\mathrm{Ya}$} & \multicolumn{2}{|c|}{ Tidak } & \\
\hline & $\mathrm{N}$ & $\%$ & $\mathrm{~N}$ & $\%$ & \\
\hline \multicolumn{6}{|l|}{ Usia } \\
\hline$\geq 5$ tahun & 48 & 96 & 2 & 4 & \multirow{2}{*}{0.001} \\
\hline$<5$ tahun & 21 & 70 & 9 & 30 & \\
\hline \multicolumn{6}{|l|}{ JenisKelamin } \\
\hline Perempuan & 41 & 93.2 & 3 & 6.8 & \multirow{2}{*}{0.047} \\
\hline Laki-laki & 28 & 77.8 & 8 & 22.2 & \\
\hline \multicolumn{6}{|l|}{ Penggunaan botol } \\
\hline Tidak & 39 & 84.8 & 7 & 15.2 & \multirow[t]{2}{*}{0.909} \\
\hline & 30 & 88.2 & 4 & 11.8 & \\
\hline \multicolumn{6}{|l|}{$\begin{array}{l}\text { Frekuensi } \\
\text { menyikat gigi }\end{array}$} \\
\hline $1 \mathrm{kali} / \mathrm{hari}$ & 15 & 88.2 & 2 & 11.8 & \multirow[t]{2}{*}{1.00} \\
\hline 2 kali/ hari & 54 & 85.7 & 9 & 14.3 & \\
\hline \multicolumn{6}{|l|}{ Peran ibu } \\
\hline Ya & 27 & 81.7 & 4 & 12.9 & \\
\hline Tidak & 42 & 85.7 & 7 & 14.3 & 1.00 \\
\hline \multicolumn{6}{|l|}{$\begin{array}{l}\text { Pendidikan orang } \\
\text { tua }\end{array}$} \\
\hline Rendah & 27 & 90 & 3 & 10 & \\
\hline Tinggi & 42 & 84 & 8 & 16 & 0.675 \\
\hline
\end{tabular}

Penilaian status ECC dengan skor def-t di interpretasikan sesuai dengan kriteria WHO ditampilkan pada Tabel5. 
FAKTOR RISIKO EARLY CHILDHOOD CARIES PADA ANAK USIA PRASEKOLAH DI

PAUD KENANGA 17 KELURAHAN PENJARINGAN, KECAMATAN PENJARINGAN, JAKARTA UTARA

Tabel 5 Skor def-t responden

\begin{tabular}{llll}
\hline $\begin{array}{l}\text { Skor } \\
\text { D }\end{array}$ & e & F & N \\
\hline 548 & 139 & 0 & 80 \\
\hline
\end{tabular}

Jumlah rata-rata def- $\mathrm{t}$

$$
-\quad 80 \frac{7+0}{\text { hasil }}=8,58
$$

Berdasarkan hasil tersebut disimpulkan bahwa dari seluruh siswa/siswi PAUD Kenanga 17, didapatkan sejumlah 548gigi mengalami karies namun masih dapat di tambal, gigi dengan keadaan berlubang/ rusak dan indikasi/ harus dicabut sejumlah 139, dan gigi anak yang sudah ditambal sejumlah 0 . Memiliki rata-rata skor def-t sejumlah 8,58 .

\section{DISKUSI}

Anak usia prasekolah merupakan salah satu kelompok rentan terhadap penyakit gigi dan mulut karena umumnya masih mempunyai perilaku atau kebiasaan diri yang kurang menunjang terhadap kesehatan gigi (Mintjelungan, 2014). Anak-anak cenderung menyukai makanmakanan manis yang lengket dan jarang membersihkan gigi setelahnya (Sumini dkk, 2014). Faktor terjadinya ECC antara lain umur, jenis kelamin, pendidikan orangtua, peran ibu, dan faktor kebiasaan (Prasetya, 2008).
Data responden dan orangtua respondenserta faktor risiko terhadap ECC diperoleh melalui kuesioner yang diisi di rumah masing-masing. Selanjutnya, setelah menyetujuiinformed consent,respondendilakukan pemeriksaan klinis untuk diambil data-datanya. Keterbatasan dalam penelitan yang dapat mempengaruhi hasil ialahterjadinya bias informasi oleh karena kuesioner yang dibawa pulang ke rumah. Kuesioner bisa diisi oleh orang tua/wali responden sendiri ataupun diwakili oleh asisten rumah tangga. Bias akibat keterbatasan orangtua responden disebabkan karena data yang diperoleh berdasarkan ingatan (recall). Bias ini dapat terjadi karena responden tidak mengingat pertanyaan yang diajukan, ragu-ragu, atau tidak tahu jawaban sehingga terjadi ketimpangan dalam keakuratan mengingat dan melaporkan paparan, sebab paparan terjadi sebelum penelitian dimulai. Bias juga dapat terjadi karena kurang ketelitian dokter dalam melakukan pemeriksaan gigi responden, yang diakibatkan keterbatasan penerangan/ cahaya di ruang kelas PAUD.

Hasil penelitian menunjukan bahwa faktor usia berhubungan terhadap ECC. Usia merupakan salah satu faktor terjadinya karies, berdasarkan data RISKESDAS terdapat kecenderungan semakin meningkat umur semakin 
meningkat yang mempunyai pengalaman karies (RISKESDAS, 2007). Penelitian ini memperlihatkan jumlah responden yang memiliki karies di usia $\geq 5$ tahun lebih banyak yaitu sejumlah 48 orang (96\%) dibandingkan dengan responden yang berusia $<5$ tahun sejumlah 21 orang (70\%). Setelah dilakukan uji statistik dengan menggunakan Chisquarememperlihatkan $\rho=0.001$ ( $\rho$ $<0.05)$. Hal ini menyatakan terdapat hubungan antara faktor usia dengan terjadinya karies.

Ghofar A, dkk (2012) berdasarkan penelitiannya menyatakan bahwa pada anak usia 5 tahun keataspaling banyak menderita karies kemungkinan karena pola makan yang kurang teratur dan ketidaktahuan menjaga kesehatan gigi sehingga dapat menyebabakan terjadinya karies.

Sejumlah 41 siswi PAUD Kenanga 17memiliki karies (93.2\%), sedangkan siswa laki-laki lebih sedikit yang memiliki karies yaitu sejumlah 28 orang (77.8\%). Analisis uji Chi-square untuk melihat hubungan jenis kelamin dengan karies, diperoleh $\rho=0.047$ ( $\rho$ $<0.05)$. Hal ini menunjukan terdapat hubungan antara jenis kelamin dengan aries.

Hasil ini sesuai dengan penelitian yang dilakukan oleh Khotimah K, dkk
(2013).Responden yang berjenis kelamin perempuan lebih banyak mengalami karies gigi dibandingkan dengan responden yang berjenis kelamin laki-laki yaitu sebesar $84,2 \%$ berbanding 56,3\%. Hasil uji statistik dengan menggunakan Chi-square didapatkan nilai $\rho=0,021(\rho<$ $0,05)$.

Begitupun dengan penelitian yang dilakukan oleh Lombo A, dkk (2015), penilaian status karies berdasarkan jenis kelamin, menunjukkan bahwa nilai def-t rata-rata pada anak perempuan lebih tinggi dibandingkan pada anak lakilaki.Perempuan mengalami percepatan pertumbuhan lebih dahulu dibandingkan laki-laki, akan tetapi besarnya percepatan pada perempuan tidak lebih besar dibandingkan dengan percepatan pertumbuhan laki-laki.

Pada penelitian ini, responden yang menggunakan botol dan mengalami ECC sejumlah 39 orang (84.8\%), sedangkan responden yang tidak menggunakan botol dan mengalami ECC sejumlah 30 orang (88.2\%). UjiChisquare antara penggunaan botol dalam mengonsumsi susu formula dengan terjadinya karies didapatkan nilai $\rho=$ 0.909 ( $\rho>0.05)$. Hal ini menunjukan tidak ada hubungan antara penggunaan botol dengan kejadian karies. 
FAKTOR RISIKO EARLY CHILDHOOD CARIES PADA ANAK USIA PRASEKOLAH DI

PAUD KENANGA 17 KELURAHAN PENJARINGAN, KECAMATAN PENJARINGAN, JAKARTA UTARA

Penelitian ini tidak sesuai dengan penelitian yang dilakukan oleh Azevedo TDP, dkk (2005).Berdasarkan penelitiannya, penggunaan botol di malam hari dan yang digunakan selama seharian secara statistik berhubungan dengan ECC dengan nilai $\rho=0,001(\rho<0,05)$. Adapun penelitian Subramaniam P,dkk (2012) menunjukan bahwa terdapat hubungan antara karies dengan penggunaan botol terutama di malam hari.Hal ini dikarenakan pada saat tidur terjadi penurunan aliran saliva dan refleks menelan, yang menyebabkan kemampuan saliva untuk menetralisir menurun (Zafar dkk, 2009). Saliva merupakan cairan protektif, rendahnya sekresi saliva dan kapasitas buffer menyebabkan berkurangnya kemampuan membersihkan sisa makanan dan mematikan mikroorganisme, kemampuan menetralisasi asam, serta kemampuan menimbulkan demineralisasi email. Suatu penurunan kecepatan sekresi saliva bisa diikuti oleh peningkatan jumlah Streptococcus mutans dan Lactobacillus(Prasetya, 2008).

Pada penelitian ini,jumlah anak yang menderita karies lebih banyak pada respondenyang mengonsumsi susu formula menggunakan botoldibandingkan dengan responden yang tidak menggunakan botol. Namun secara presentase jumlah anak yang terjadi karies dengan menggunakan botol lebih rendah dibandingkan dengan yang tidak menggunakan botol, hal ini mungkin dikarenakan pengambilan jumlah sampel yang kurang banyak sehingga mempengaruhi hasil penelitian.

$$
\text { Penggunaan botol bukan }
$$

merupakan faktor utama penyebab karies. Menurut Wirjayadi, dkk (2013) faktor utama penyebab kerusakan gigi adalah host, mikroorganisme, substrat, dan waktu. Selain faktor utama terdapat pula faktor-faktor predisposisi lainnya, yaitu keadaan penduduk dan lingkungan, pengetahuan,kesadaran, dan perilaku yang berhubungan dengan kesehatan gigi, misalnya pengetahuan tentang makanan dan minuman yang menyebabkan karies atau kerusakan gigi.

Dalam penelitian ini terlihat bahwa siswa/siswi PAUD Kenanga 17 sebagian besar memiliki kebiasaan menyikat gigi 2 kali/ hari sebanyak 63 orang (78.8\%), dengan jumlah frekuensi responden yang menyikat gigi pagi dan sebelum tidur lebih banyak dibandingkan yang tidak. Setelah dilakukan analisis data dengan menggunakan uji Chi-square untuk melihat hubungan antara kebiasaan menyikat gigi dengan terjadinya karies didapatkan nilai $\rho=1.00(\rho>0.05)$, dapat disimpulkan tidak ada hubungan antara 
kebiasaan menyikat gigi dengan terjadinya karies.

Penelitian ini bertolak belakang dengan penelitian yang dilakukan oleh Khotimah K, dkk (2013). Responden yang menggosok gigi $<2 \mathrm{kali} /$ hari lebih besar mengalami kejadian karies gigi dibandingkan dengan responden yang menggosok gigi $\geq 2 \mathrm{kali} / \mathrm{hari}$. Hasil uji statistik dengan menggunakan fisher's exact didapatkan nilai $\rho=0,14(\rho<0,05)$. Pada hasil penelitian di PAUD Kenanga 17, anak dengan frekuensi menyikat gigi 2 kali/hari memperlihatkan jumlah karies yang lebih banyak dibandingkan dengan yang menyikat gigi $1 \mathrm{kali} / \mathrm{hari}$. Meskipun frekuensi menyikat gigi 2 kali/hari, mungkin saja tingkat kebersihan gigi masih belum baik sehingga tingkat kerusakan gigi lebih besar (Robke, 2008).Adapun hal lainnya yaitu mungkin disebabkan cara menyikat gigi yang kurang tepat, kurangnya partisipasi orangtua selama penyikatan dan tidak menggunakan pasta gigi yang mengandung fluoride. Pasta gigi yang mengandung fluoride dapat mengurangi produksi asam dan meningkatkan pembentukan mineral pada gigi dan hal ini telah terbukti menurunkan risiko karies (Subramaniam dan Prashanth, 2012)

Kesehatan anak prasekolah dipengaruhi oleh perilaku keluarga khususnya perilaku ibu(Kuriakose dkk, 2015). Pada penelitian ini, peran ibu dinilai dengan melihat apakah ibu menggunakan alat makan bergantian dengan anaknya. Bakteri Streptococcus mutans dapat tertular melalui orang tua ke anak dengan banyak cara salah satunya perilaku ibu yang menggunakan alat makan bergantian dengan anaknya (Kuriakose dkk, 2015). Terlihat bahwa jumlah responden dengan terjadinya karies sebagian besar tidak menggunakan alat makan bergantian yaitu sejumlah 42 orang $(85.7 \%)$ dibandingkan dengan yang menggunakan alat makan bergantian sejumlah 27 orang $(81.7 \%)$.Setelah dilakukan analisis data dengan uji Chisquare didapatkan nilai $\rho=1.00(\rho>$ $0.05)$.

Dapat disimpulkan bahwa tidak ada hubungan antara peran ibu dengan terjadinya karies pada siswa/siswi PAUD Kenanga 17. Penggunaan alat makan bergantian bukan merupakan satu-satunya faktor yang dapat menjadi perantara perpindahan bakteri Streptococcus mutans dari ibu ke anak, melainkan ada beberapa cara yaitu mencium anak dibagian mulut, minum dari gelas yang sama dan membersihkan dot susu dengan cara meletakan di mulut ibu kemudian memberikannya pada bayi. 
FAKTOR RISIKO EARLY CHILDHOOD CARIES PADA ANAK USIA PRASEKOLAH DI

PAUD KENANGA 17 KELURAHAN PENJARINGAN, KECAMATAN PENJARINGAN, JAKARTA UTARA

Penelitian ini juga melihat

Berdasarkan hasil pemeriksaan

hubungan antara tingkat pendidikan menurut indikator def-t didapatkan orangtua dengan terjadinya karies pada anak, jumlah anak dengan orangtua berpendidikan tinggi dan memiliki karies sejumah 42 orang $(84 \%)$ sedangkan anak dengan yang orang tua berpendidikan rendah yang memiliki karies sejumlah 27 orang (90\%). Uji analisis dengan menggunakan Chi-square didapatkan nilai $\rho=0.675(\rho>0.05)$, dapat disimpulkan tidak terdapat hubungan yang bermakna antara tingkat pendidikan orangtua dengan terjadinya karies. Penelitian ini sejalan dengan penelitian yang dilakukan oleh Susi, dkk (2012)dengan nilai $\rho=0.490$ untuk pendidikan ayah dan $\rho=0.146$ untuk pendidikan ibu yang menyatakan bahwa tidak ada hubungan yang bermakna antara tingkat pendidikan orangtua dengan status karies yang dialami responden. Pengambilan jumlah sampel yang kurang proporsional ini mungkin mempengaruhi hasil penelitian ini.

Kurangnya informasi dan pendidikan tentang perawatan kesehatan mulut bagi anak-anak di antara ibu-ibu yang tidak berpendidikan dan rendahnya kesadaran orangtua tentang kesehatan mulut merupakan salah satu faktor yang mempengaruhi terjadinya karies anak (Kuriakose dkk,2015). prevalensi karies adalah 86,3\%, artinya dari 80 orang murid terdapat 69 orang yang telah mengalami karies. Rerata skor def-tsiswa/siswi PAUD Kenanga 17 sebesar 8,58 yang menunjukan bahwa satu siswa/siswi PAUD Kenanga 17 setidaknya memiliki 9 gigi yang telah atau sedang mengalami karies. Berdasarkan kategori WHO, indeks def-t pada murid PAUD Kenanga 17 di kelurahan Penjaringan, kecamatan Penjaringan, Jakarta utara, termasuk dalam kategori sangat tinggi.

\section{SIMPULAN DAN SARAN}

\section{Simpulan}

Status ECCpada anak usia prasekolah di PAUD Kenanga 17berada dikategori sangat tinggi. Faktor resiko yang memiliki hubungan dengan terjadinya EEC pada anak usia prasekolah di PAUD Kenanga 17 kelurahan Penjaringan, kecamatan Penjaringan adalah usia dan jenis kelamin.

\section{Saran}

Berdasarkan hasil penelitian, disarankan untuk dilakukan pembinaan terhadap siswa/siswi, guru beserta orang tua mengenai pentingnya kesehatan gigi anak. Hal ini dapat dilakukan dalam 
bentuk penyuluhan dan pemeriksaan rutin sehingga diharapkan dapat meningkatkan peran serta orang tua dan berkurangnya kejadian karies gigi pada anak usia prasekolah di PAUD Kenanga 17, kelurahan Penjaringan, kecamatan Penjaringan. Selain itu, perlunya dilakukan penelitian lebih lanjut mengenai faktor risiko yang lain terhadap EEC dengan jumlah sampel yang lebih banyak.

\section{KEPUSTAKAAN}

Azevedo TDP, Bezerra ACB, de Toledo OA 2005. Feeding habits and severe early childhood caries in Brazilian preschool children. Pediatr Dent; 27(1):28-33.

Gofar A, Firmansyah A 2012. Hubungan gigi karies terhadap status gizi anak $\mathrm{Tk}$ muslimat 7 peterongan jombang. J.Edu Health;2(2):1-13.

Hasil Riskesdas 2007. Badan penelitian dan pengembangan Kesehatan Kementrian Kesehatan RI; p.130,132.

Hasil Riskesdas 2013. Badan penelitian dan pengembangan Kesehatan Kementrian Kesehatan RI;p.146-7.

Khotima K, Suhadi N, Purnomo 2013. Faktorfaktor yang berhubungan dengan kejadian karies gigi pada anak usia 6-12 tahun di SD Negeri Karangayu 03 Semarang. J Ilmu Keperawatan dan Kebinanan;1(4):1-10.

Kuriakose S, Prasannan M, Remya KC, Kurian J, Srejith KR 2015. Prevalence of early childhood caries among preschool children in Trivandrum and its associated with various risk factors. Contemporary clinic dentistry;6:69-73.

Lombo A, Mayulu N, Gunawan PN 2015. Status karies anak prasekolah citra kasih yang mengkonsumsi susu formula. J.eG;3(1).

Mintjelungan CN 2014. Prevalensi karies gigi sulung anak prasekolah di Kecamatan Malayang kota Manado. J Biomedik;6(2):105-9.

Prasetya RC. 2008. Perbandingan jumlah koloni bakteri saliva pada anak-anak karies dan non karies setelah mengkonsumsi minuman berkarbonasi. Indonesia J.D;15(1):65-70.

Robke FZ 2008. Effects of nursing bottle misuse on oral health prevalence of caries, tooth malalignments and malocclusions in North-German preschool children. J Orofac Orthop;(1):5-19

Subramaniam P, Prashanth P 2012. Prevalence of early childhood caries in 8 - 48 month old preschool children of Bangalore city, South India. Contemporary clinic dentistry;3:15-21. Sumini, Amikasari B, Nurhayati D 2014. Hubungan Konsumsi Makanan Manis Dengan Kejadian Karies Gigi Pada Anak Prasekolah Di TK B RA Muslimat PSM Tegalrejodesa Semen Kecamatan Nguntoronadi Kabupaten Magetan. J Delima Harapan; 3(2):20-7. 
FAKTOR RISIKO EARLY CHILDHOOD CARIES PADA ANAK USIA PRASEKOLAH DI

PAUD KENANGA 17 KELURAHAN PENJARINGAN, KECAMATAN PENJARINGAN,

JAKARTA UTARA

Supariani NN, Artawa IM, Wirata IN 2013. Wirjayadi, Kadir A, Askar M 2013. Faktor

Hubungan karbohidrat pada susu yang

dikonsumsi dengan kejadian karies gigi

botol pada anak play group. J Kes

G;1(1):27-31

Susi, Bachtiar H, Azmi U 2012. Hubungan status sosial ekonomi orangtua dengan karies pada gigi sulung anak umur 4 dan 5 tahun. Majalah Kedokteran Andalas;36(1):96-105. yang berhubungan dengan kerusakan gigi pada anak usia pra sekolah di Tk Kartika XX-1 Makassar. J.Ilmiah Kesehatan;1(6):1-8.

Zafar S, Harnekar SY, Sidiqi A 2009. Early childhood caries: etiology, clinical considerations, consequences and management. Int Dent ;11(4):24-36. 